\title{
Exploring gender differences in the EFL classroom
}

\author{
Norma Constanza Durán
}

\begin{abstract}
This article aims to describe a case study which explores teacher and students' conceptions about gender in an EFL setting and the way they are manifested in their discourse patterns. This exploratory case study was carried out with a group of eleventh grade students and an English teacher at Liceo de la Universidad Católica high school in Bogotá Colombia. The data collected included direct observation of classroom interaction, audio and video recording of the teacher and students 'interactions and interviews on the teacher's and students' discourse. The analysis of the data revealed that in fact there are imbalances in relation to boys ' and girls ' participation during interaction, made manifest by verbal and nonverbal attitudes. There is also sound evidence of girls' low self esteem in response to the lack of value and respect granted to their opinions by their male peers. Stereotypes are part of teachers' and students' conceptions regarding gender and thus they are maintained to a great extent. The teacher's attitude in the classroom with respect to boys and girls also appeared to show inequality that favoured boys. The girls showed evidence of awareness of the teacher's conscious or unconscious indifference towards them, which seemed to affect their autonomy and confidence as English language learners.
\end{abstract}

key words : Gender, teacher and students interaction, gender and discourse, inequity, self esteem and ELT English language teaching.

\section{Resumen}

El propósito de este artículo es describir un estudio de caso que explora las concepciones de profesores sobre género en un contexto de enseñanza del inglés como lengua extranjera, y la forma como dichas concepciones se manifiestan en sus actos discursivos. Este estudio se llevó a cabo con un grupo de estudiantes de once grado y una profesora de inglés del Liceo de bachillerato de la Universidad Católica en la ciudad de Bogotá. La información recolectada incluyó observación directa de la interacción en el aula. Se audio y video grabaron las interacciones en el salón al igual que las entrevistas realizadas sobre el discurso de profesor y estudiantes. El análisis de información reveló que de hecho hay desequilibrio en la participación de los y las estudiantes en interacciones, evidenciada por actitudes verbales y no verbales. También hay evidencia de baja autoestima en las estudiantes como respuesta a la falta de valor y respeto otorgado a sus opiniones por parte de sus compañeros de sexo masculino. Los estereotipos también hacen parte de las concepciones de los, las estudiantes y la docente con relación a género. La actitud de la docente con respecto a los estudiantes y las estudiantes tendió a favorecer más a los hombres. Las estudiantes mostraron evidencia de percibir consciente 0 inconsciente indiferencia de la docente hacia ellas, lo que parece afectar su autonomía y confianza como estudiantes de Inglés.

Palabras Claves: Género, interacción de estudiantes y docente, género y discurso, inequidad, autoestima y enseñanza del Inglés como lengua extranjera.

* Received: 15-06-06 / Accepted: 03-08-06 


\section{Introduction}

Gender issues have been studied in different academic arenas and from different perspectives. However, for the EFL field this is an area that has been scarcely explored. This report addresses the topic of gender from an exploratory point of view that examines teacher and students' discourse and interactions. Research in the area, as well as trends like critical pedagogy, have shown the need to adopt positions regarding the ways a social formation like gender is linked to questions of power and inequality

(Pennycook, 2001). In consequence, with no interest in falling into active feminism but looking at what real local context currently reveals, I hope to bring about a better understanding of how gender matters related to the teacher and students involved may influence daily school practices and possible perpetuation of imbalance.

Examining what happens in local EFL settings in connection with cultural features, stereotypes and awareness on social identity values or imbalance, this study intends to show the need to see beyond the way teachers think and act in relation to gender issues, how the latter are revealed in classrooms dynamics and their unavoidable impact on students' and in particular teenagers' present and future lives. It is also my intention, with respect to school contexts, to contribute expanding knowledge and information about these types of social issues and their influence in the language classroom. In addition, via the findings I seek to encourage teachers to adopt more critical positions regarding gender, to become more aware of this fact and to foster the use of more balanced teaching strategies, to strengthen boys' and girls' self esteem, to combat sexist stereotypes and in general to reflect upon the language use referring to gender, and to imagine new inclusive forms of speaking in academic environments.

Next, I will present the theoretical foundations that guided this study, beginning with a definition of gender, as well as the main pillars that supported the research. I will continue with the research design, followed by the description of the findings and finally I will present the conclusions and pedagogical implications .

\section{Theoretical framework}

\section{Towards a definition of gender}

Due to the novelty of the topic of gender in the ELT field, I consider it relevant to define the term to help the reader contextualize the reason of this study, Tischler 
(1996) states that gender pertains to the socially learned patterns of behaviour and the psychological or emotional expressions or attitudes that distinguish males from females. Looking at gender as a permanent construction, behaviours like talking, dressing and body language are embedded in all social interactions and informed by social contexts. Gender is something we do as we talk, act, read and write in ways that constitute us as masculine or feminine within social structures (Zimmerman and West, 1987) In this regard and from the thoughts presented, it is clear that gender responds to a social construction which shapes people's self images and identities. In the next section I will present how gender, discourse and interaction also played a key role in this research.

\section{Gender, discourse and interaction}

Concerning the teacher's discourse, studies have dealt with the amount and type of attention the teacher gives in mixed sex classes, especially in EFL settings, based on teachers' and students' perceptions. Non verbal behaviour, like teachers' gaze or eye contact and differential treatment according to gender also play an important role in classroom dynamics, and become indicators of male or female students' marginalization. Regarding learners discourse, several studies have suggested that boys talk more than girls, and in general that the role of the learner gender in the classroom is reflected in talk in pair and group work, turn taking, topic choice and interruptions. Through the interaction of individuals involved in classroom events, prior experiences, assumptions, expectations, values and students' world view in general become apparent, and consequently there is an influence of such features in the process of production and interpretation. Therefore, it becomes important to understand how male and female students and teachers position themselves and each other through their interactions in the language classroom (Freeman, 1996). In addition, teachers ' perceptions of gender were also analysed as a crucial component of classroom interaction and of direct influence on the teachers attitudes and behaviours with respect to the students.

\section{Teachers` world views}

Teachers ' perceptions have to do initially with the way we move about in the world, we create a model of how the world works. A common factor about 
perceptions regarding gender, is that they tend to be the result of the way we have been taught in relation to stereotypes and prejudices. With respect to the way teachers see themselves in relation to the way they treat the students according to gender, we teachers do not think much of gender influence in our classroom practices, or take for granted that our performance in class reflects equitable opportunities for mixed sex learners and in general that our classroom environment does not promote imbalances. However, research findings reveal that teachers treat male and female students differently ( $\mathrm{Li}$, 1999). In addition, lesson transcripts (Sunderland, 1996) have shown that teachers of mixed classes pay more attention to male students. Other authors like Poynton (1985) and Freeman (1996) also coincide with the fact that even when teachers think that they distribute their attention equally, what actually happened is that girls received much less time. This situation demonstrates the relevance of exploring the discrepancy between what the teacher thinks he or she was doing and what they were actually doing. As for the students, their age was another influential unit in this study which also determined the students ' points of view and performance in interaction.

\section{Adolescence}

Many authors coincide with the idea that adolescence is a stage during which a lot of changes occur, that range from physical and hormonal, to pressure from parents, school and friends, and in general the adaptation to new experiences and in consequence to new roles. The adoption and internalization of new roles and the transition from one stage to another in the course of life, is a time of learning and experimenting in anticipation of more complex adult roles (Kornblum, 1991). Differential and stereotyped roles are transmitted via family, school and society in general. These largely become contributors to raise adolescents' self - image and self - esteem in a positive or negative way. Some adolescent students feel caught between parental demands for academic success and peer pressures for engaging in social life. Most students combine elements of both into their self images.

The way teachers and students play their social roles in the classroom, and how issues of power and equality are explicit within the educational context are addressed in the following section by critical pedagogy. 


\section{Critical Pedagogy}

Critical pedagogy is one of the current and strongest supports for this type of study, which entails reflection of the larger society beyond the classroom walls and a place where social relations are played out and therefore questions of social power should be addressed. In addition, it requires an understanding of how discourses operate across multiple sites, constructing our worlds and subjectivities, and how to deal with the particularities and complexities of these issues by trying to take differences seriously (Pennycook, 2001).

In the next section, the type of study, the population chosen and the way the data was collected is explained.

\section{The study}

The characteristics of the present study call for a qualitative exploratory case study. It is qualitative in the sense that it is aimed at looking at teachers and students' perceptions of the world (Bell, 1999) in this case, with regard to gender.

\section{Setting and population}

The context selected for this research was a school that belonged to La Universidad Católica . It is a private school whose philosophy embraces the preservation of catholic values and holistic education. The population chosen for the development of this study, is a coeducational (mixed sex) group English class of 11 th grade students, taught by one female teacher. Their ages range between 15 and 16 years old and most of them belong to a middle social class. The criteria for choosing such a population responds mainly to the sensitiveness of the issue and the conditions required to study a topic of this nature. High school students are generally facing adolescence, identified as a crucial period in the development of a gender identity because they are transforming a childhood gender identity into an adult one. Whitehead (1996).

\section{Data collection}

In accordance with the characteristics and type of the present study, some of the most appropriate tools for collecting information involved field notes from 
direct observation of classes which focused specifically on teachers' and students' discourse and the way they interacted with each other. The notes taken during the observation were later complemented and contrasted with both the audio and tape recorded information. These observations were held for a total of eight months, once a week for 90 minutes each session. Additionally, audio and video recordings provided a valuable record of words actually uttered and gestures actually made. Transcripts were excellent for analyzing specific and accurate aspects of a particular interaction (Hopkins, 1995). Subsequently, to examine teachers' and students' conceptions on gender, Interviews were a way to address them and to dig into their value system, their world view and to know about their feelings and reasons for behaving in a certain way and reaction to others' attitude. These interviews were done in small groups with the students, where they expressed different feelings and perceptions about classrooms events and their peers. With the teacher it was done in an individual way.

Subsequently, I include a description of the process followed to analyze the data and after, the questions that I attempted to answer.

\section{Data analysis}

The analysis of the information involved progressive and permanent reading and reflection of a great deal of the field notes, which was complemented by the transcriptions of the video and audio recordings. As the analysis progressed and the collection of data was completed, I followed the principals of the grounded approach for data analysis (Freeman, 1998). These involve labeling the data in some way but separately which means taking the data apart and giving them a name. Then, grouping was necessary to reassemble the names into categories. A color coding system was used as a means to providing salient patterns and possible themes related to the research questions. Grouping of themes and after contrasting and reflecting on the resulting panorama,, as well as, doing different matrixes of the emerging patterns as the analysis evolved was a helpful procedure. I developed a progressive process of noting commonalities, reflecting on group and individual stances and conversational exchanges, explanations and persistent facts that showed the way to identify two broad categories that were recurrent in the different phases of the examination of results. I used triangulation, which is to employ multiple sources of data to confirm the emerging findings (Merriam, 1998). 


\section{Research Questions}

The use of the above instruments guided the path to answer the following research questions

1. What do T-S / SS-SS classroom oral discourse and interaction patterns tell us about gender relations in an EFL setting?

2. How are T-S / Ss-Ss gender conceptions revealed in their reflections about the discourse used in the EFL classroom?

\section{Findings}

In this section the main aspects revealed through the data analysis are described and supported. After the analysis of the data collected, two main categories emerged which allowed me to answer the above mentioned research questions. The first category was named source and workings of domination and other interpersonal intentions and effects. I retake the idea that gender is a social process that is created, renegotiated in interpersonal relationships and encouraged and maintained through social structures. (Weatherall, 2002). I also agree with the idea that schools are spaces for socialization and interpersonal relationships. These processes take place through language conversational exchanges that become meaningful depending on the circumstances and scenarios. From the analysis I made of several episodes where students showed conversational modes, it was possible to identify certain common ways of performing and addressing others in a conversation. In the light of theory, the conversational modes observed in the students are called linguistic strategies which refer simply to a way of speaking (Tannen, 1996 ). In addition, the age of the students is a vulnerable factor in terms of shaping identity and also their social status and family-transmitted value system plays a role in the way they assume dominant or subordinated postures in conversation and interaction. The strategies most frequently found in the data analysis were interruptions that led to dominance. In one of the episodes, in a one boy and two girls group, the boy spoke and made jokes. The girls laughed and seemed to be enjoying the conversation but their voices were not visibly heard. This is a very common situation where boys play the leading role and girls assume a receptive attitude mainly. Another strategy has to do with silence versus volubility. In this respect, a girl commented as a result of interaction with boys: 
" cuando uno dice algo mal o que no es, se lo viven estregando. Uno prefiere no decir nada.

Many expressions like the above were frequently found and most of them showed a marginalization feeling among girls as a result of interaction with boys. The strategy called topic raising and verbal conflict was reflected in statements like the following, where a girl who attempted to switch a topic was confronted by an aggressive male response:

Diana Patarroyo : Bueno niños por favor trabajemos.

Rafael: Ah no usted no quiere nada!. Nada a toda hora ustedes ponen problema. Perereques. (He looked angry and the girl kept silent) .

Another very common situation demonstrated an unheard position generally played by girls as a result of their interaction with boys:

Ginet: grite o no grite no me van a poner atención .

The analysis of the strategies used by the teacher also showed how her discourse as well as her attitude, generated differential treatment towards the students, permeating a sense of preferences among them and the consolidation of strong and weak learners in the English class.

The second category called Characterizing teachers and students' ideologies as shapers of gendered roles in classroom processes, was aimed to respond to the question about how the teachers and students gender conceptions were revealed in their reflections about the discourse and interaction in the EFL classroom. The students in this study showed their evolving conceptions about the opposite sex and at the same time, such conceptions operated as shapers of their own identity as well as their peers.

The above was reflected when the students were asked about their preference when working in groups. In the next episodes the students expressed their view about working in mixed gender groups, the advantages of such interactions and also highlighted positive and negative qualities of the opposite and same sex.

Ginet: Pues que sea más equilibrado no porque hay algunas cosas que los hombres son mejores en que las mujeres son mejores. Por ejemplo yo 
siempre trabajo con Nidia, Johan y Maritza y como que siempre estamos equilibrados.

Diana: Yo con los dos. Hay personas con las que yo me haría y personas con las que sepan pues inglés, pues porque me ayudan a estudiar. Yo me haría con los que pueda trabajar, con niños y con niñas. Con los dos.

También es bueno trabajar con niños, porque a veces las niñas somos como más conflictivas. Los niños pelean menos".

In many cases girls favored working in mixed gender groups. Regarding boys, when they were asked about their feelings and preference when working in groups, their opinions diverged:

11. Johan: Mal . mal porque me toca regirme por lo que ellas digan. Pues simplemente si yo digo algo que a ellas no les gusta pues se van a poner así en sus términos, ellas se van a poner a exaltarse mucho y casi siempre pues uno no puede opinar porque de pronto ellas tienen razón o algo así. Ellas piensan mucho más rápido... y uno no puede molestar tanto porque simplemente no esta con los del grupo de uno y entonces toca regirse.

4. Diego: A mi me da igual. Siempre y cuando trabajen pues me da igual.

15. Diego: Lo llevan a uno a lo que ellas opinan porque son mayoría y son mujeres.

16. R: Y que pasa que sean mujeres?

17. Ricardo: En ese caso ellas tienen como más autonomía, mejor dicho ellas no se pueden adecuar a lo que uno esta diciendo. Porque ahí tienen ellas el privilegio de elegir, de escoger.

In contrast to the above comments, some female students stated their interest and the advantages of working with girls:

A: "Prefiero trabajar con las niñas aunque hay más equilibrio con niños, si trabajan y no son perezosos.

Ivan: Si hay un trabajo en grupo prefiero trabajar con mujeres. Es tanto a veces la confianza con esa persona que uno se pone a recochar con los hombres. En cambio con las mujeres pues más seriedad.

M: Me siento más a gusto trabajando solo con niñas. Es que los niños recochan mucho.

In these findings based on the students' voice it was confirmed that women are seen as more responsible and that when working with them, boys were 
more likely to succeed in tasks to be completed in groups. This idea is reinforced by the following excerpts.

G: pues yo siempre trabajo con los dos pero me gusta más con las niñas.

Trabajan mejor y se ponen más serias.

41. Johan ; pues yo en especial con una mujer. Pues la que más sabe inglés.

Con eso me ayuda y como que dice por donde es el camino.

On the other hand, the teacher in this study seemed not to be very aware of the implications of certain unbalanced attitudes on her part, that may also contribute to encouraging or maintaining stereotyped responses and sometimes students' belittled conceptions about themselves. When talking to the students about the dynamics in their interaction with the teacher, they underlined that the teacher generally focused her attention on a boy called Sebastian and a girl called Nidia. They both are the best students at English in her class. When I asked a group of students about their perception on any type of preference on the teachers' part, they answered in unison:

4. . Hmmmm Quién va a ser?

6. C: un poco más de atención en Nidia y Juan Sebastián, se muestran más interesados en la clase.

In an interview with the teacher, she responded to the students' comments:

9. A: A ver yo no lo juzgo como más atención lo que pasa es que yo lanzó una pregunta. No la respondió al que le correspondía y la responde el que sabe y se le da la palabra a ese y entonces ellos creen que hay preferencia.

10. A: Por ejemplo corrigiendo el ICFES. Teníamos una discusión sobre la interpretación de graficas. Entonces Juan Sebastián siempre esta tratando de rebatir y rebatir las cosas

11. Entonces claro yo me centro en corregirle, decirle y explicarle por que si o por qué no, entonces de pronto eso es lo que ellos perciben como mayor atención.

13. A: Yo no lo percibo como una preferencia no. Ellos son los que más saben. Entonces claro los demás se sienten desplazados porque los que más participan son ellos. In another part of the interview I asked her:

En cuanto a interacción directa que tu tengas con unos y otros, tu crees que le dedicas el mismo tiempo, la misma atención a niños y niñas? 
33..A: Si. a lo mejor me encuentro con algunas sorpresas (laughing ) pero yo lo que he percibido es que a todos los trato de igual manera.

With the above samples and many others analyzed, it is clear that the students shape their own image and their peers' as a result of interaction and the dynamics within it. In the teachers' case her lack of awareness was also visible, not only in terms of the differences in treatment towards the students but also the impact of such differential treatment on the students' feelings and performance as learners in the present and in the future.

The next part presents the conclusions and implications that should be considered at a pedagogical level in EFL contexts and educational communities in general.

\section{Conclusions and pedagogical implications}

Considering that the main constructs of this study were gender and the T-SS/SS-SS discourse in interaction and their conceptions about the same topic, it was evident that interruptions reflected boys dominance, girls' silence in response to such dominance and also verbal conflict that tended to reinforce a submissive role in girls and which was displayed as an aggressor role in boys. Thus, physical contact like hitting or pinching was also noticeable as an element used by boys and girls indistinctly, but with different purposes; in the case of girls, who were frequently seen taking the initiative, it was a technique to self defend, protest or gain the boys' attention. This was also a way to show students asserting themselves in more resistant and proactive roles, regarding their right to talk and positioning in mixed gender groups.

At times the teachers' treatment toward the students revealed invisibility of apparently harmless behavior, such as eye contact and quantity and quality of attention and praise, favouring boys in this case, and leaving girls excluded. From this stand point I can conclude that when we, as teachers, consciously or unconsciously neglect or accept students' and our own behavior that excludes or undervalues boys or girls in the classroom, the perpetuation of them may be ensured.

In terms of the students' perception in relation to their interaction in mixed gender groups and their male and female peers, they both reported that they acknowledge the benefits of mixed gender groups because of the opportunity 
to share, contribute and have more fun. However, they also clearly stated that they felt more comfortable working with same gender students. Boys were recognized by girls as lazy and witty but not very responsible. Girls on their part, were considered by a good number of boys as responsible, autonomous, aggressive and controllers when completing English class tasks.

One of the most meaningful and serious findings in my opinion, was the case of a girl who displayed a continuous and extremely low level of selfesteem and self value with respect to her right to talk and in general her low status within interaction. Such feelings were made stronger by her classmates' lack of respect and recognition because of her public and recurrent lack of assertiveness. I draw on this matter because I think it is a reflection of how gender is the product of social interaction that may create unfavorable conditions for the students', either boys or girls, and this may have a definite impact on their future social and professional lives.

The lack of teachers' awareness of signs of favouritism or differential treatment towards the students was also unveiled. This is an aspect that should be addressed critically because institutions and language use within them are powerful perpetuators of gender inequality.

It is relevant to foresee ways in which gender stereotypes may be reverted into opportunities in social relationships between males and females, which can be acknowledged rather than stigmatized. To encourage environments that drop hierarchical and exclusive relations and which, in contrast, encourage equity and respect that help students to be active participants of more symmetrical social relations and interactions in their future lives as women and men, are highly important.

It is advisable for teachers to tackle the social relationships that students bring with them when interacting. As reinforced by Guzzeti, Peyton, Gritsavage, Fyfe and Hardenbrook, ( 2002) they should also help students to identify and reflect on possible gendered practices in language, call attention to balanced face to face interactions in the language classroom and model the students on how to encourage contributions to a group work discussion and how to build on others' comments.

Discourse analysis techniques can also be taken into consideration and fostered by recording students' language or talk in interactions in order to track 
power relations: for example who asserts, who asks questions, who responds, who gains, holds or gets the conversational floor dropped, the same with identification of participation patterns frequencies and type of participation in small groups. (Guzzeti,, Peyton, ,Gritsavage, Fyfe and Hardenbrook, 2002)

It is important for us as teachers to get informed about issues like gender, how it can be manifested and how it can be handled. In this way we would be more careful and monitor our performance as language teachers more closely and so avoid differences in the treatment of the students. It is also essential for us to know how to identify the ways in which students are marginalized by gender interactions, and how language helps to reproduce or reinforce patterns that allow inequity and undermining feelings to emerge.

Considering also that language is a potential shaper of imbalances, and highlighting the practicality of this type of study in demonstrating that students' understandings are formed and expressed by language (Vygotsky, 1978). Talking with the students about their interactional discourse may help to develop a sense of awareness, tolerance, respect and confidence that promotes equity, while valuing male and female voices, not only in the EFL classroom, but in society in general.

\section{References}

Bell, J. (1999). Doing your research project. London. Open University Press.

Freeman, D. (1998) Doing teacher-research from inquiry to understanding. London: Heinle \& Heinle Publishers.

Freeman, R \& McElhinny, (1997) Language and gender. Sociolinguistics and Language Teaching. London. Cambridge University Press.

Freeman, R (1996 ) Language Planning and identity planning for social change. Washington, DC: Georgetown University.

Guzzeti, B., Peyton, J .,Gritsavage, M., Fyfe L., and Hardenbrook, M. (2002). Reading, writing, and talking gender in literacy learning. Chicago. International Reading Association.

Kornblum, W. (1991) Sociology in a changing world $2^{\text {nd }}$ edition Saunders College Publishing. Orlando Florida.

Li, Q. (1999) Teachers beliefs and gender differences in mathematics: a review. The Journal of Educational Research , 43, (1). 
Merrian, S. (1998) Qualitative Research and case study. Applications in education. San Francisco: Jossey - Bass Publisher.

Poynton, C. (1985). Language and gender: Making the difference. Oxford: Oxford University Press.

Pennycook, A. (2001) Critical Applied linguistics. London, Lawrence Erlbaum Associates.

Sunderland, J. (1996) Exploring gender: Questions and implications for English language education. USA. Prentice Hall.

Tischler, L. (1996). Introduction to Sociology. Sixth edition. Harcourt Brace College publishers. USA.

Tannen, D (1996) Gender and discourse. New York, Oxford University Press.

Vygotsky, L. (1978) Mind in Society: The development if higher education process, Cambridge, Harvard University Press.

Weatherall, A. (2002) Gender, language and discourse. New York, Routledge.

Zimmerman, $\mathrm{H}$ and West, C. (1987) Sex roles, interruptions and silences in conversation. Newbury House.

\section{THE AUTHORS}

Norma Constanza Duràn Narváez. Full time teacher and consultant of teacher education programmes at Universidad de Ibagué. M.A. in Applied Linguistics from Universidad Distrital Francisco José de Caldas. Specialist in English Language Teaching from Universidad del Tolima. E-mail: ncduran23@yahoo.com 